\title{
Surprising reasons owners exit family businesses
}

\author{
James Hoffman \\ Ritch Sorenson (University of St. Thomas) \\ Keith Brigham (Texas Tech University)
}

KEYWORDS: Leadership, Strategy, Family Business, Conflict.

An issue often raised in family business studies is that only about a third of family businesses make it to the second generation. Often, the implication is that owners have not adequately prepared for succession.

This study examines another explanation for the twothirds that don't make it to the next generation: the owner chooses to leave the business. This study examines factors that may be associated with why owners choose to leave or stay in the business. This is an important issue given research has shown that the owner-manager plays a major role in family businesses and that others highly depend on them (Feltham, Feltham, \& Barnett, 2005). Owner-managers can establish and sustain entrepreneurial values (Sorenson, 2015); have an impact on both devotion and performance in their firms (Kidwell \& Kloepfer, 2018); and manage conflict (Sorenson, 1999).

Two issues that are important to the success of family businesses are owner-manager satisfaction and intention to exit the firm (Khanin, Turel, \& Mahto, 2013). These individual psychosocial outcomes are important for family business owners and their firms for many reasons. One reason is that family firms are characterized by a concern for family relationships and succession (Poza, 2007). Cooper and Artz (1995) posit that an entrepreneur's level of satisfaction might be viewed as a fundamental measure of performance. Furthermore, an owner's level of satisfaction may influence relationships with employees and customers and decisions regarding investing more time and resources in the business or even closing or leaving the firm (Cooper \& Artz, 1995).

Cooper and Artz (1995) also state that, "satisfaction is clearly a fundamental measure of success for the individual entrepreneur" (p. 440). In addition, as organizational leaders play a decisive role in shaping

their firms' strategic directions and outcomes (Ghosal \& Lovas, 2000), owner-manager satisfaction and intentions to exit may ultimately impact firm performance, survival, and transitions within family firms (Cooper \& Artz, 1995, Sadler-Smith, 2004).

Although an owner-manager's level of satisfaction and expressed intentions to exit the family firm would appear to be critical, they have rarely been included as either independent or dependent variables in research efforts pertaining to family firms. A notable exception is the study by Boles (1996), which examined owners' satisfaction and intentions to remain with their firms. Another exception is that satisfaction has been included with respect to the succession process in some models and studies (e.g., Sharma, Chrisman, \& Chua, 2003; Morris, Williams, Allen, \& Avila, 1997). Most recently, Khanin et al. (2013) examined how to increase job satisfaction and reduce turnover intentions from a familybusiness embeddedness perspective.

To further investigate determinants of satisfaction and intentions to exit for family firm owner-managers, we explore both individual and firm level variables. The individual level variables include ownership experience, whether the owner was the founder of the business, and the owner-manager's age. The firm-level variables include succession planning, the degree of conflict in the business, firm profitability, and firm size.

The rest of the paper proceeds as follows. First, literature pertaining to different determinants of satisfaction and intentions to exit for family firm ownermanagers is reviewed. Hypotheses pertaining to the relationships between determinants of satisfaction and intentions to exit for family firm owner-managers are then developed. Next, the methodology used to test our hypotheses is presented. Results from the analyses are then presented. The paper ends with a discussion of the

Copyright (C) 2020 The Authors. Entrepreneur \& Innovation Exchange is published at EIX.org. This is an open access article under the terms of the Creative Commons Attribution-NoDerivs License, which permits use and distribution in any medium, provided the original work is properly cited and 
implications from our findings along with a discussion of the limitations associated with our study and future research directions.

\section{THEORETICAL BACKGROUND Person-organization Fit}

An underlying problem facing many family firm ownermanagers is maintaining a good fit with their firms over time. The concepts of fit and contingency are found in numerous theories across management disciplines. Within the field of organizational behavior, one of the dominant streams of research is Person-Organization Fit (P-O fit). $\mathrm{P}-\mathrm{O}$ fit research focuses on the dimensions and consequences of compatibility between people and their jobs or the organizations in which they work (Kristof, 1996). A fundamental tenet of this approach is that both individual and firm level factors should be incorporated and when there is congruence between relevant individual and organizational factors, individuals will experience better outcomes (Kristof, 1996). In P-O fit studies, employee outcomes often include job satisfaction, stress, intentions to exit/remain and turnover (e.g., Chatman, 1991; O'Reilly, Chatman \& Caldwell, 1991) among others. These outcomes are contingent, in part, on key facets of the employee and the firm.

Increasingly, researchers have espoused the potential benefits of extending the traditional P-O fit approach from employees in large established firms to entrepreneurs and owner-managers in entrepreneurial contexts and SMEs (Baron \& Markman, 2003; Brigham \& De Castro, 2003). With respect to family business, Dyer (1994) argues that incorporating more organizational behavior approaches and variables can add much to the understanding of the dynamics of family firms. Morris et al. (1997) propose that to understand the succession process, greater attention should be given to the complex human interactions and levels of satisfaction that occur within family businesses. The identification and analysis of key variables which could be employed to assess the congruence between the individual owner and their organization has yet to be thoroughly explored in the family business literature.

Thus, following a P-O fit perspective, we take an important first step by identifying and testing the relationship of several individual and firm level variables on the dependent outcomes of owner-manager satisfaction and intentions to exit their firms. Specific hypotheses are developed below.

\section{Hypotheses Characteristics of the Owner}

As mentioned above, based on previous studies that examined similar dependent variables (e.g., Cooper \& Artz, 1995; O'Reilly et al., 1991), we theorize that ownership experience, whether the owner was the founder of the business, and owner's age will affect an owner's level of satisfaction and intentions to leave their firm.

Research on owner-manager experience has suggested that owner-managers who stay in one business may eventually plateau and devote their energies to activities outside of their business (Malone and Jenster, 1992). This research suggests that the more businesses an owner-manager has been involved with, the less likely they are to plateau, which may affect both their level of satisfaction and their intentions to exit their current firm. Research has also argued that work experiences in an entrepreneur's prior firm shape both the entrepreneur's competence and commitment to the entrepreneurial role (Sorenson \& Phillips, 2011).

In addition to this research, an argument can be made that owner-managers who have worked in more than one business and thus have experienced life on the other side of the fence may also not be as susceptible to the notion that the grass is always greener on the other side of the fence, thus increasing their level of satisfaction and decreasing their intentions to exit their current firm. This additional business experience may also make them more keenly aware of both the benefits and costs of exiting a firm. Based on this reasoning the following hypotheses are put forth.

Hypothesis 1a. Owner-managers with more experience have higher levels of satisfaction.

Hypothesis 1b. Owner-managers with more experience have lower intentions to exit.

Regarding differences between founders and nonfounders, research has also suggested that founders may have different attitudes towards their firms than nonfounders and may experience acute role conflict as their firm's mature (Dobrev \& Barnett, 2005). Specifically, Dobrev and Barnett (2005) argue that effects of role are contingent on the founder's charismatic identity, and the decoupling of this identity from the organization as it grows and ages. Founders often have stronger identity 
and emotional bonds to their firms than non-founders (e.g., Hoang \& Jimeno, 2010), which may lead to greater satisfaction and lower intentions to leave. Based on these arguments the following hypotheses are put forth.

Hypothesis 2a. Founders have a higher level of satisfaction than non-founders.

Hypothesis 2b. Founders' intentions to exit are lower than non-founders.

Currently, little research has examined the effect of age on owner-manager satisfaction and intentions to exit family businesses. Marshall et al. (2006) found a positive relationship between owner age and formal succession planning in family firms. This suggests that there may be a relationship among owner-manager age and thinking about stepping aside and leaving the family firm. Furthermore, Kooij et al. (2011) conducted an extensive literature review and performed a metaanalysis to investigate the relationship between age and work-related motives. Results from their study showed a significant positive relationship between age and intrinsic motives, and a significant negative relationship between age, strength of growth, and extrinsic motives. Based on their extensive literature review and results the following hypotheses are put forth.

Hypothesis 3a. As owner-managers get older their level of satisfaction will increase.

Hypothesis $3 b$. As owner-managers get older their intentions to exit will increase.

\section{Characteristics of the Firm}

Succession is major challenge for family businesses and successful successions are rarely smooth (Astrachan, 2019). Complicating this is that many potential successors of family businesses forgo joining the family business at first, so they can become entrepreneurs themselves (Kammerlander \& Leitner, 2018). Previous research has examined satisfaction related to the succession process (Sharma, Chrisman, Pablo, \& Chua, 2001; Sharma et al., 2003) and having a succession plan in place could influence an owner's intention to exit or remain with the firm - as a plan may set a date for transition that is not continually pushed back. Specifically, Sharma et al. (2003) found that satisfaction with the succession process in family firms is enhanced by succession planning, the incumbent's propensity to step aside, the successor's willingness to take over, agreement among family members to maintain family involvement in the business, and acceptance of individual roles. Based on this research the following hypotheses are put forth.

Hypothesis 4a. Having a succession plan in place will increase an owner-managers level of satisfaction.

Hypothesis 4b. Having a succession plan in place will increase owner-managers intentions to exit.

Conflict is an important variable in many family business studies (Poza, 2007, Sorenson, 1999) and would appear to be linked to the individual outcomes at hand. Sorenson (1999) found that family businesses have a more complex set of issues to consider when managing conflict than non-family businesses. Research that has specifically examined whether conflict in family businesses significantly affects job satisfaction of owners as well as their propensity to seek a new line of work has produced mixed results. Although Kwan, Lau, and $\mathrm{Au}$ (2012) did not find a link between family-to-work conflict and business owner satisfaction in Chinese family businesses, research by Boles (1996) suggests that work-family conflict can significantly affect job satisfaction of owners as well as their propensity to seek a new line of work. In the current study we theorize that work-family conflict can significantly affect job satisfaction of owners as well as their propensity to seek a new line of work. Specifically, the following hypotheses are put forth:

Hypothesis 5a. Higher levels of conflict will decrease owner-managers level of satisfaction.

Hypothesis $5 \mathbf{b}$. Higher levels of conflict will increase owner-managers intentions to exit.

Firm performance has been included in previous studies when looking at individual predictors of owner satisfaction (Brigham, De Castro, \& Shepherd, 2007; Cooper \& Artz, 1995) and intentions to exit (Brigham et al., 2007). This research suggests that profitability has a positive effect on owner-manager satisfaction and decreases an owner-manager's intention to exit the firm. Based on this research the following hypotheses are put forth:

Hypothesis 6a. Higher levels of profitability will increase owner-managers level of satisfaction. 
Hypothesis 6b. Higher levels of profitability will decrease owner-managers intentions to exit.

Research on firm size has indicated that size affects several different organizational factors such as structure (Ford and Slocum, 1977), innovation (Damanpour, 1992), strategy and performance (Smith, Guthrie, \& Chen, 1989). Currently however, little research has examined the effect of family firm size on ownermanager satisfaction and intentions to exit family businesses. Based on results from prior research that has examined the effect of size on several different organizational factors, strong arguments can be made that an increase in size could increase or for that matter decrease an owner-managers level of satisfaction and intentions to exit. From an exploratory perspective, we theorize that as organizations get larger the bond ownermanagers have with their businesses grows leading to increased satisfaction and lowering their intentions to exit. Specifically, the following hypotheses are put forth.

Hypothesis 7a. As a firm's size increases, ownermanagers level of satisfaction increases.

Hypothesis 7b. As a firm's size increases, ownermanagers intentions to exit will decrease.

\section{Methods}

\section{Sample}

The initial data used in this study was collected in the United States between 1997 and 1999. Data were gathered in two ways. First, using the Internet, Chambers of Commerce were identified from cities across the U.S. and businesses from those cities were randomly selected to participate and were contacted by telephone. If theirs was a family business, they were asked to complete the survey. Twenty percent returned a completed survey. Second, for class credit, students asked family business owners to complete questionnaires about their businesses. Seventy percent of those business owners contacted by the students agreed to complete the questionnaires. The use of student informants to identify rare populations has been used in previous entrepreneurship research (Stewart, Watson, Carland, \& Carland, 1999). This type of mixed sampling procedure has been used in other studies of family businesses (e.g., Marshall et al., 2006, Sorenson, Folker \& Brigham, 2008). The total original completed database consisted of 393 (182 student identified, and 211 telephone identified) businesses.
In 2002, a follow up study on these firms that had completed the original survey was conducted. Through multiple contacts (both mail and phone), 211 of the follow up questionnaires were received. All the variables included in models for this study were measured at this second data collection point. Additional contacts by mail, telephone, and the Internet verified that some businesses were no longer available for contact. To test the hypotheses, it was necessary to further refine our sample. We used responses to ensure that our sample of firms met a definition of a family business. Following Poza (2007), we included only firms where at least 15 percent of the ownership of the business was held by the family and the family firm owner-manager had ownership in the firm and was involved in the day-to day management of the firm. Furthermore, we removed all firms that did not have at least one full time employee in addition to the owner and had less than 250 full time employees. This meets the accepted definition of a SME and left 155 owner-managers on which the analyses in this study were conducted.

\section{Variables and Measures}

Several of the variables and measures used in this study were used in previous $\mathrm{P}-\mathrm{O}$ fit studies examining similar dependent variables. Additionally, where possible, we followed the approach of Brigham et al. (2007). For comparative purposes we have reported the reliabilities from that study where appropriate.

\section{Dependent variables}

Satisfaction. This was measured using a scale of "facet free job satisfaction" developed by Quinn and Staines (1979, p. 205). They define satisfaction as an "affective reaction to the job," and this established measure is described fully in the Handbook of Organizational Measurement (Price \& Mueller, 1986: 220-223). The scale consists of five items scored on a Likert-type scale and possible scores range from 5 to 25 . For ease of comparison to other studies using this measure, we use and report the summed score for all five items. This measure was employed by Brigham et al. (2007) who reported that alpha $=.75$. For the present study, alpha $=$ .75 .

Intentions to Exit. This was measured using four items, each scored on a 7-point Likert-type scale. These items were employed by O'Reilly et al. (1991), who reported that a Principal Components Analysis yielded a single 
factor. Examples of items are: "If you have your own way, will you be working for this organization three years from now?" and "How long do you intend to remain with this organization?" Since the response scales varied by item, we used the average of the summed $z$ scores for the four items. This measure was employed by Brigham et al. (2007) who reported that $a=.76$. For the present study, $a=.68$.

\section{Independent Variables}

Owner's age. This was measured in years and the natural log transformation of this number was used.

Ownership experience. This variable was included with a single item, which asked the respondent the number of businesses they had previously founded, purchased or inherited over their career (Brigham et al, 2007).

Founder of the family business. Founder was coded as 1 and non-founder was coded as 0 .

Succession planning. This was measured through two items: "Do you have a formal plan for developing a successor in your business?" and "Have you developed a formal plan for succession in your business?" Responses to both questions were coded as $0=$ no and 1 = yes. We summed the scores for both items and divided by two. For the measure, alpha $=.87$.

Degree of Conflict. We measured this through three items. An example stem question was "How much anger is expressed among members of your business during disagreements?" Responses to all three questions were indicated on a five-point Likert-type scale ranging from none to a great deal. We summed the scores for all items and divided by three. For the measure, alpha $=.86$.

Firm Profitability. This was indicated by a single-item subjective measure of performance in which the respondent was asked "Has your business earned profits in the last five years?" Responses were recorded on a four-point scale ranging from not in the last five years to all of the last five years.

Firm Size. This was measured through the number of full-time employees in the firm and the natural log transformation of this number was used in the models.

\section{RESULTS}

\section{Means and Correlations}

Means, standard deviations, and inter-correlations for the variables used in the models are presented in Table 1 (See Appendix).

In general, the firms included in the study exhibit characteristics we would expect from small established firms. While the correlations between variables were generally as expected, the highest correlation (-.63) between satisfaction and intentions to exit merits discussion. As expected from previous research, Brigham et al. (2007) reported a similar correlation (-.61), these two measures were significantly negatively correlated. Despite the high correlation, they are distinct constructs and are often included as dependent variables in the same study (Brigham et al., 2007; Kristoff, 1996).

\section{Regression Models}

To test the hypotheses, we followed the approach of Brigham et al. (2007) and used hierarchical regression analyses in SPSS. The results are reported in Table 2 (See Appendix).

Variables were entered in blocks to allow for a clear demonstration of the additional variance explained by different groups of variables. The first block, labeled "Owner," includes three individual-level owner variables. The second block, labeled "Firm," includes the addition of four firm-level variables. Table 3 (see Appendix) lists all the hypotheses that were supported along with all the hypotheses that were not supported.

\section{Discussion, Implications and Limitations, and Opportunities for Future Research}

For the dependent variable satisfaction, the "Owner" variables were generally poor predictors with only being a founder of the family firm significantly associated with greater satisfaction. The "Firm" level variables fared better with two of the four being significant predictors. Profitability was significant and positively associated, while conflict was significant and negatively associated. However, firm size and succession planning were not significant. Thus, efforts to reduce conflict may help owners to achieve greater satisfaction. However, while succession planning is viewed as an important process and outcome and for family firms, in this study it was not significantly related to higher owner satisfaction. 
For the dependent variable intentions to exit, the "Owner" variables were also generally poor predictors with owner's age being the only individual level variable that was positively associated with greater intentions to exit. However, "Firm" level variables were highly influential with all but succession planning being significant predictors (three out of four variables). Both firm size and profitability were significant and negatively associated as expected. Conflict was significant and positively associated.

\section{Implications for Owners}

The major implications for owners from this study are that firm-level variables may add potential

underlying explanations for failure of family firms to transition to future generations (Zahra \& Sharma, 2004). Previous research has focused largely on succession planning to remedy failed transitions. These results suggest that other remedies ought to be considered. For example, low profitability and high conflict accounted for a sizable portion of variance in explaining low satisfaction and intentions to exit. Thus, owners, researchers and consultants might focus on fundamental issues relative to making family firms profitable as one basis for promoting transitions. Focusing/maintaining firm growth may be another basis for promoting transitions. Another area of focus would be promoting management practices such as collaboration to reduce conflict (Sorenson, 1999). Owner-managers focusing time on living a healthy lifestyle might also help curb some of the effects of aging and facilitate a smoother transition.

\section{Limitations \& Opportunities for Future Research}

This study, as with all studies, has several limitations and opportunities for future research. First, we focused on owner-managers of small family firms. Care must be taken in generalizing our results. Second, we investigated intentions rather than behavior. Although there appears to be a strong link between the strength of an intention and subsequent behavior (Azjen, 1991) and significant associations between intentions to exit and actual turnover have been demonstrated in the P-O fit literature (Chatman, 1991) and for owners of SMEs (Brigham et al., 2007), we must acknowledge that other factors can intervene between intentions and behavior. Such investigations of behavior will require longitudinal designs. Also, our research design does not establish causality, so caution should be taken not infer more than associations between variables.

Third, as is often the case with field survey studies, it is impossible to rule out common method bias. Same source bias is more common in certain types of questions than others even within the same selfreported instrument (Crampton \& Wagner, 1994). Items asking for demographic information seldom exhibit effect-size inflation and more concrete constructs may be less susceptible than more abstract constructs (Podsakoff \& Organ, 1986). Many of the items in this study are demographic or factual in nature. Also, great care was taken in the questionnaire to reduce all sources of bias possible through question creation, and ordering.

Finally, while we identified several individual and firm level variables that were significantly associated with the outcomes of interest, this study did not actually assess the fit or congruence between individual and firm variables. Future research could build on our initial study and identify how these and/or other variables may interact to further explain the outcomes of interest.

\section{REFERENCES}

Ajzen, I. (1991). The theory of planned behavior. Organizational Behavior and Human Decision Processes, 50: 179-211.

Astrachan, C. B. (2019). Successful successions are never smooth. Entrepreneur \& Innovation Exchange. Published online at FamilyBusiness.org on March 11, 2019.

Baron, R.A. and Markman, G.D. (2003). Beyond social capital: The role of entrepreneurs' social competence in their financial success. Journal of Business Venturing, 18: 41-60.

Boles, J. S. (1996). Influences of work-family conflict on job satisfaction, life satisfaction and quitting intentions among business owners: The case of family-operated businesses Family Business Review, 9(1): 61-74.

Brigham, K. H., \& De Castro, J. O. (2003). Entrepreneurial fit: The role of cognitive misfit. In J. A. Katz \& D. A. Shepherd (Eds.), Advances in Entrepreneurship, Firm Emergence, and Growth. vol. 6: 37-72. Oxford, UK: Elsevier/JAI Press.

Brigham, K. H., De Castro, J. O., \& Shepherd, D. A. 
(2007). A person-organization fit model of ownermanagers' cognitive style and organizational demands. Entrepreneurship Theory \& Practice, 31(1): 29-51.

Chatman, J. A. (1991). Matching people and organizations: Selection and socialization in public accounting firms. Administrative Science Quarterly, 36: 459-484.

Cooper, A. C., \& Artz, K. C. (1995). Determinants of satisfaction for entrepreneurs. Journal of Business Venturing, 10(6): 439-457.

Crampton, S. M., \& Wagner, J. A. (1994). Percept inflationin micro-organizational research: an investigation of prevalence and effect. Journal of Applied Psychology, 79 (1): 67-76.

Damanpour, F. (1992). Organizational size and innovation. Organization Studies, 13(3): 375-402.

Dobrev, S. D., \& Barnett, W. P. (2005). Organizational roles and transition to entrepreneurship. Academy of Management Journal, 48, 433-449.

Dyer, Jr. W. G. (1994). Potential contributors of organizational behavior to the study of family-owned businesses. Family Business Review, 12, 109-131.

Feltham, T., Feltham, G., Barnett, J. (2005). The dependence of family businesses on a single decisionmaker. Journal of Small business Management, 43(1): $1-15$

Ford, J.D., \& Slocum, J.W. (1977). Size, technology, environment and the structure of organizations. Academy Management Review, 2(4): 561-575.

Ghosal, S., \& Lovas, B. (2000). Strategy as guided evolution. Strategic Management Journal, 21(9): 875-896.

Hoang, H., \& Gimeno, J. (2010). Becoming a founder: How founder role identity affects entrepreneurial transitions and persistence in founding. Journal of Business Venturing, 25(1), 41-53.

Kammerlander, N. \& Leitner, L. (2018). When entrepreneurs raise entrepreneurs. Entrepreneur Innovation Exchange. Published online at FamilyBusiness.org on September 17, 2018.
Khanin, D., Turel, O., Mahto, R. (2013). How to increase job satisfaction and reduce turnover intentions in the family firm: The family-business embeddedness perspective. Family Business Review, 25(4): 391-408.

Kidwell, R. \& Kloepfer, K. (2018). How family business leaders can encourage both devotion and performance. Entrepreneur Innovation Exchange, Published online at FamilyBusiness.org on August 29, 2018.

Kristof, A. L. (1996). Person-organization fit: An integrative review of its conceptualizations, measurement, and implications. Personnel Psychology, 49: 1-48.

Kooij, D., De Lange, A., Jansen, P., Kanfer, R., Dikkers, J. (2011). Age and work-related motives: Results of a meta-analysis. Journal of Organizational Behavior, 32(2): 197-225.

Kwan, H.K., Lau, V.P., Au, K, 2012. Effects of family-towork conflict on business owners: The role of family business. Family Business Review: 25: 178-190.

Malone, S.C. \& Jenster, P.V. (1992). The problem for the plateaued owner-manager. Family

Business Review, 5(25): 25-41.

Marshall, J. P., Sorenson, R. L., Brigham, K. H., Wieling, E., Reifman, A., \& Wampler, R. (2006).

The Paradox for the Family Firm CEO: Owner Age Relationship to Succession-Related Processes and Plans. Journal of Business Venturing, 21(3): 348-368.

Morris, M. H., Williams, R. O., Allen, J. A., \& Avila, R. A. (1997). Correlations of success in family business transitions. Journal of Business Venturing, 12(5), 385-401.

O'Reilly, C. A. III, Chatman, J., \& Caldwell, D. F. (1991). People and organizational culture: A profile comparison approach to assessing person-organization fit. Academy of Management Journal, 34: 487-516.

Poza, E. J. (2007). Family Business. Mason, OH: Thompson South-Western.

Podsakoff, P. M., \& Organ, D. W. (1986). Self-reports in organizational research: problems and prospects. Journal of Management, 12, 4: 531-543. 
Price, J. L., \& Mueller, C. W. (1986). Handbook of organizational measurement. Cambridge, MA: Ballinger.

Quinn, R. P., \& Staines, G. L. (1979). The 1977 quality of employment survey. Ann Arbor, Ml: University of Michigan.

Sadler-Smith, E. (2004). Cognitive style and the management of small and medium-sized enterprises. Organization Studies, 25(2): 155-181.

Sharma, P., Chrisman, J. J., \& Chua, J. H. (2003). Predictors of satisfaction with the succession process in family firms. Journal of Business Venturing, 18(5): 667-687.

Sharma, P., Chrisman, J.J., Pablo, A., \& Chua, J.H. (2001). "Determinants of initial satisfaction with the succession process in family firms: A conceptual model". Entrepreneurship Theory and Practice, 25 (3), 1-19.

Smith, K.G., Guthrie, J.P., Chen, M.J. (1989). Strategy, size, and performance. Organization Studies, 10(1): 63-81.

Sorenson, J.B. and Phillips, D.J. (2011). Competence and commitment: Employer size and entrepreneurial endurance. Industrial and Corporate Change, 20(5): 1277-1304.

Sorenson, R. L. (1999). Conflict strategies used by successful family businesses. Family Business Review, 12, 325-339.

Sorenson, R. L., Folker, C., \& Brigham, K. H. (2008). The Collaborative Network Orientation: Achieving Business Success through Collaborative Relationships. Entrepreneurship Theory \& Practice.

Sorenson, R. L. (2015). The family way: How entrepreneurial values help businesses thrive over generations. Entrepreneur Innovation Exchange, Published online at FamilyBusiness.org on January 12, 2015.

Stewart, W. H. Jr., Watson, W. E., Carland, J. C., \& Carland, J. W. (1999). A proclivity for entrepreneurship: A comparison of entrepreneurs, small business owners, and corporate managers. Journal of Business Venturing, 14(2): 189-214.
Zahra, S. A., \& Sharma, P. (2004). Family business research: A strategic reflection. Family Business Review, 17(4): 331-346.

Additional Search Terms: Family Business Satisfaction, Intentions to Exit, Succession Planning 


\section{Appendix}

\section{TABLE 1}

\section{Means, Standard Deviations, and Correlations ${ }^{a}$}

$\begin{array}{lllllllllll}\text { Mean } & \text { s.d. } & 1 & 2 & 3 & 4 & 5 & 6 & 7 & 8 & 9\end{array}$

1. Satisfa20.83 4.80

ction

2. $2.04 \quad 1.18 \quad-.63^{* *}$

Intention

to Exit

$\begin{array}{lllll}3 . & .55 & .50 & .15 & .12\end{array}$

Founder

$\begin{array}{lllll}\text { 4. Owner1.30 } & 1.95 & .14 & -.06 & .12\end{array}$

ship Expe

rience

$\begin{array}{llllll}\text { 5. Owner51.35 } & 10.50 & .09 & .20^{*} & .23^{\star *} & -.08\end{array}$

Age

6. Full20.23 $33.47 \quad .13 \quad-.18^{*} \quad \begin{array}{lllll} & -.18^{*} & .04 & .01\end{array}$

time Emp

loyees

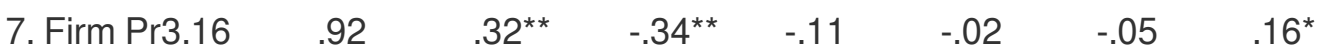

ofitability

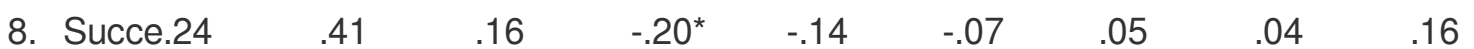

ssion

Planning

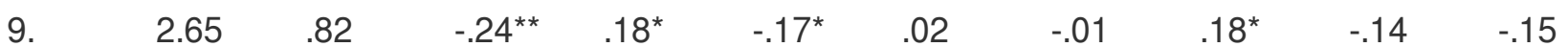

Conflict

$\mathrm{a}=155$

${ }^{* *}$ Correlation is significant at the .01 level ( 2 tailed).

* Correlation is significant at the .01 level (2 tailed). 


\section{TABLE 2}

Results of Hierarchical Regression Analysis: Satisfaction and Intentions to Exit.

Satisfaction

Owner
Firm

Owner
Firm

Variable

Intentions to Exit

\author{
Owner
}

\section{(Constant)}

Founder

Experience

Age (Ln)

FTEs (Ln)

Profitability

Succession

Planning

\section{Conflict}

$\mathbf{R}^{2}$

Adjusted $\mathbf{R}^{2}$

.039

$-1.16^{*}$

.53

$1.44^{\star \star \star}$

1.14

$-2.04$

$-1.65$

1.17

1.60 *

.12

.03

.34

$-.02$

$-.25$

.51

$.54^{\star}$

$-.13^{\star *}$

$-.18^{\star \star}$

$-.20$

$\mathbf{R}^{2}$ Change

.020

.177

.023

.193

Unstandardized Beta Coefficients are reported (Following Aiken \& West, 1991).

$\mathrm{n}=155$

${ }^{* * *}$ significant at $\mathrm{p}<.001$

** significant at $\mathrm{p}<.01$

* significant at $p<.05$
Copyright (C) 2020 James Hoffman, Ritch Sorenson, Keith Brigham, Published by Entrepreneur \& Innovation Exchange
FamilyBusiness.org (2020) 


\section{TABLE 3}

\section{Hypotheses that were supported}

Hypothesis 2a. Founders have a higher level of satisfaction than non-founders.

Hypothesis $3 b$. As owner-managers get older their intentions to exit will increase.

Hypothesis 5a. Higher levels of conflict will decrease an owner-managers level of satisfaction.

Hypothesis $\mathbf{5 b}$. Higher levels of conflict will increase owner-managers intentions to exit.

Hypothesis 6a. Higher levels of profitability will increase owner-managers level of satisfaction.

Hypothesis $\mathbf{6 b}$. Higher levels of profitability will decrease an owner-managers intention to exit.

Hypothesis 7b. As a firm's size increases, an owner-managers intention to exit will decrease.

\section{Hypotheses that were not supported}

Hypothesis 1a. Owner-managers with more experience have higher levels of satisfaction.

Hypothesis 1b. Owner-managers with more experience have lower intentions to exit.

Hypothesis $\mathbf{2 b}$. Founders intentions to exit are lower than non-founders.

Hypothesis 3a. As owner-managers get older their level of satisfaction will increase.

Hypothesis 4a. Having a succession plan in place will increase owner-managers level of satisfaction.

Hypothesis $\mathbf{4 b}$. Having a succession plan in place will increase owner-managers intentions to exit.

Hypothesis 7a. As a firm's size increases, an owner-managers level of satisfaction increases. 